\title{
SPATIAL STATISTICS FOR MAPPING SOLID WASTE GENERATION MAPPING IN TEMBALANG, SEMARANG CITY
}

\author{
S. Y. Ardiansyah ${ }^{\mathrm{a}}$, M. Maryono ${ }^{\mathrm{b}}$ \\ ${ }^{a}$ Master of Urban and Regional Development in Diponegoro University, Indonesia \\ ${ }^{b}$ Department of Urban and Regional Planning in Diponegoro University, Indonesia
}

\section{Article Info:}

Received: 7 July 2017

in revised form: 10 Dec 2017

Accepted: 30 January 2018

Available Online: 25 April 2018

\section{Keywords:}

Spatial Statistics, Waste

Generation, Ordinary Least

Square

\section{Corresponding Author:}

Septa Yudha Ardiansyah

Urban and Regional Planning in

Diponegoro University, Indonesia

Email:

septayudha573@gmail.com

\begin{abstract}
The annually increasing number of urban populations will have impacts on waste generation. Tembalang Sub-district as a sub-district located on the outskirts of Semarang City has significant developments in the term of population growth in correlation with waste generation. Within four years, waste generation in the Tembalang Sub-district increased from the fifth rank to the third rank. It is possible that this sub-district will become the first rank in Semarang City in waste generation. To be able to identify influential factors and spatial distribution pattern of waste generation in Tembalang Sub-district, it is necessary to apply statistical and spatial approach. This study uses quantitative methods with a statistical spatial analysis approach by using GIS. In addition, this research also intends to model the relationships of Solid Waste Generation by applying socio-economic variables. Based on the results of Ordinary Least Square analysis, social economy variables that affect the amount of waste generation in Tembalang Subdistrict are the number of population and trading activities. The model of formed socio-economic variables has the effect of $25 \%$ towards the amount of waste generation. Spatial patterns identified from waste generation shows that what needs to be considered is the waste management in TPS (Temporary Waste Disposal) in Tembalang and Sendangmulyo.
\end{abstract}

How to cite (APA 6th style): Ardiansyah S. Y \& Maryono, M. (2018). Spatial statistics for mapping solid waste generation mapping in tembalang, semarang city. Geoplanning: Journal of Geomatics and Planning, 5(1), 163-174. doi: 10.14710/geoplanning.5.1.163-174

\section{INTRODUCTION}

Solid Waste Generation problem is a common problem faced by developing countries. The increasing number of urban waste is caused by increasing population and urbanization (JICA, 2005). Waste is the remaining part of human activities that needs to be managed properly so as not to cause problems to human life or disturbance to the environment such as environmental pollution, the spread of disease, reduced aesthetics and as a carrier of the disease. The problem of waste management is very serious in urban areas due to the complexity of the problems and high population density, so waste management is often a prioritized handling in urban areas (Moersid, 2004). Waste management in Indonesian cities has yet to achieve optimum results. Population number has been one of the reasons why wastes in cities are piling up so high (Damanhuri et al., 2010).

Previous studies only focused on the flow of solid waste management processes, but they did not specify link between waste generation and the spatial aspects (Olukanni et al., 2014). Mapping provides the exact location, amount, and type of garbage. Waste mapping had also been done although only limited to location mapping and the paths used to dump waste (Lee et al,. 2015).

To find out how big the influence of urban waste generation, the identification requires a spatial approach to make it more easily understandable (Yousif \& Scott, 2007). In the context of spatial data, it can be seen how the patterns are formed by the spread of the existence of waste generation.

In this study, the author intends to identify spatially the distribution of waste generation in Tembalang Sub-district. This research's objective is to map waste dumping spots and to derive cross-factor relationships from related socioeconomic factors. The exact pattern of waste generation will show which 
areas have the highest concentrations from which then a waste handling method can be formulated. The analytical method used is quantitative analysis with the spatial approach by using spatial statistics analysis. Ordinary Least Square (OLS) models are used to determine the relationship that is formed from the spread of waste generation. The author uses the software Arc Map 10.1.

\section{DATA AND METHODS}

\subsection{Study area}

Tembalang Sub-district is one of Semarang City suburbs that has been developed very rapidly. This suburb has its own pull factors for the people to settle and live there. The development activities of this sub-district are also characterized by the presence of Diponegoro University that turns this area to experience function changes of the former rice fields, gardens, and fields into trading activities, housing and boarding houses for students. People who live in Tembalang are not only from Semarang City but also from out of town or province.

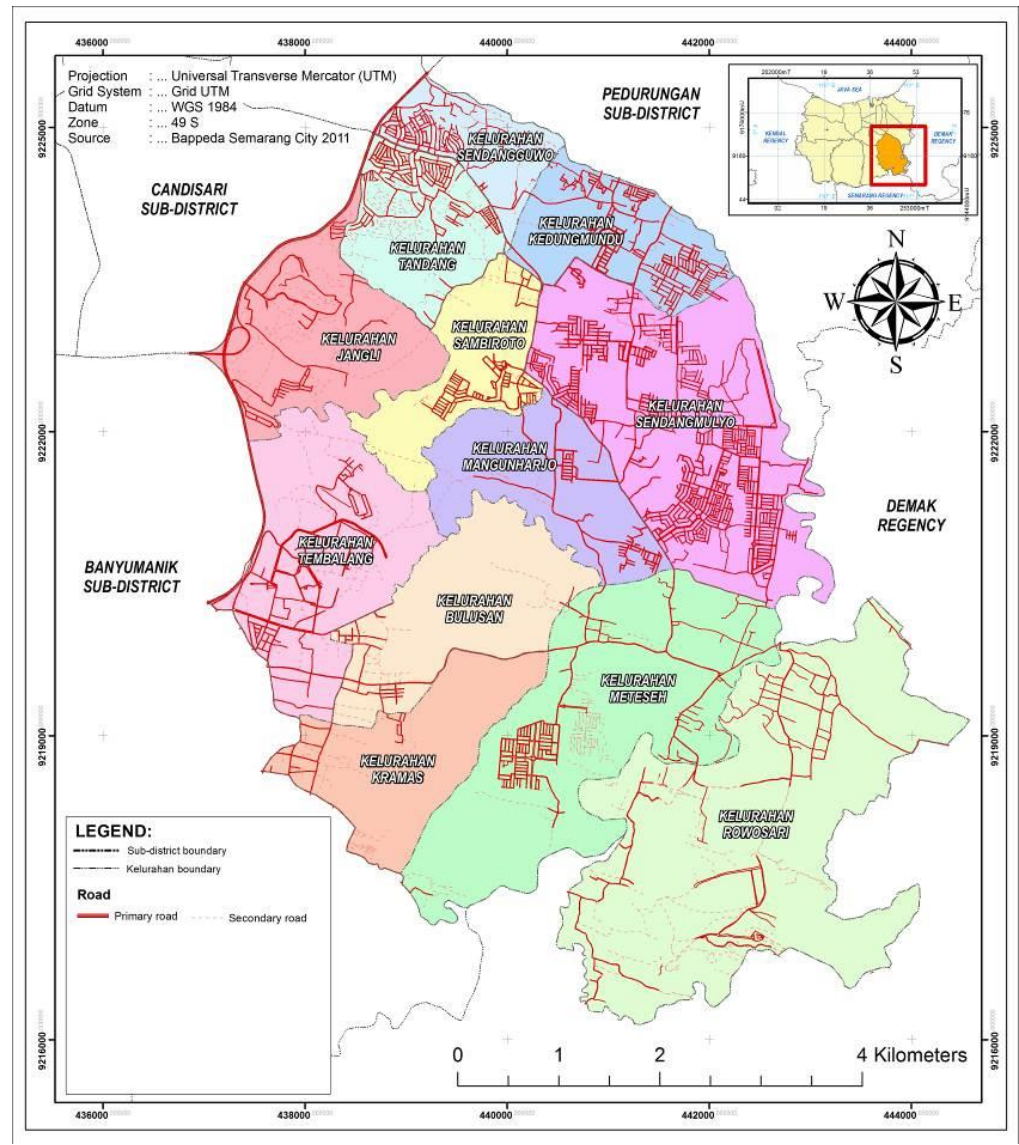

Figure 1. Administrative Map of Tembalang Sub-district

With an area of $41.74 \mathrm{~km} 2$, Tembalang Sub-district consists of 12 villages which are Rowosari, Meteseh, Kramas, Tembalang, Bulusan, Tandang, Mangunharjo, Sendangmulyo, Jangli, Sambiroto, Kedungmundu, and Sendangguwo (Figure 1). The population of Tembalang Sub-district in 2015 amounted to 154,697 inhabitants and is the second highest number of inhabitants in Semarang City after Pedurungan Sub-district. Total average production of waste / day in Tembalang Sub-district is the second largest in Semarang which amounted to $325.29 \mathrm{m3} /$ day (CBS, 2015). This means that the average waste generated by Tembalang society is a sizeable $2.35 \mathrm{~kg} /$ day.

Each year, the waste generation in Tembalang Sub-district has increased in an average of about 1.73 tons per year (Figure 2). Generally, Tembalang sub-district has 5 units of arm roll trucks, 28 units of truck containers, and 30 plots of landfills. Based on the data from DKP (Cleaning and Landscaping Agency) of Semarang City, the current situation of waste generation in Tembalang Sub-district is already handled as 
much as $83 \%$. This means that the remaining $17 \%$ of waste is still piled up and cannot be addressed by the government.

108

Volume

(Ton)

106

104

102

104.86

100

98

96

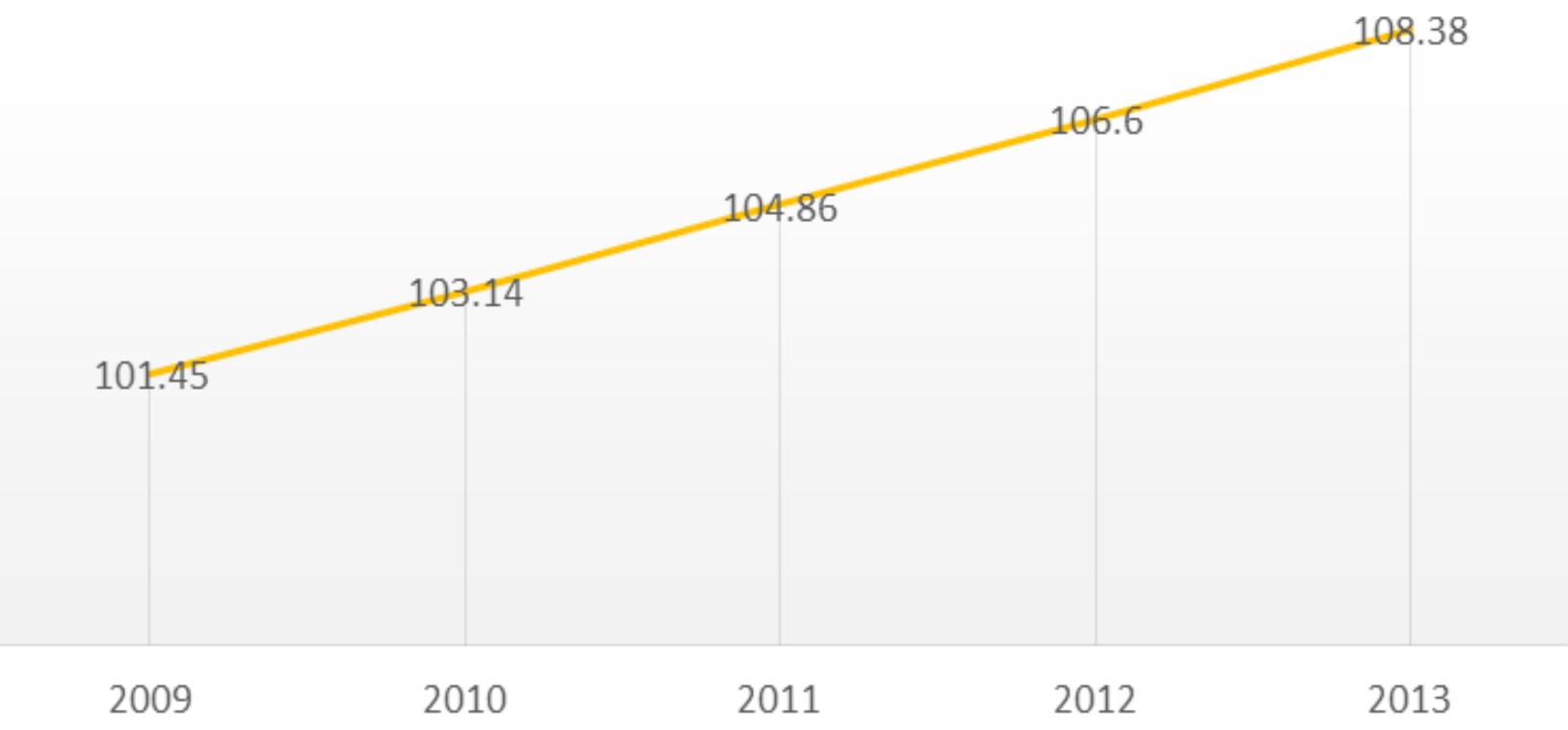

Figure 2. Total Number of Waste Generation in Tembalang Sub-district (DKP, 2015)

Table 1. TPS Name, Container Amount and Estimation of Daily Waste Generation Tembalang Sub-district (CBS, 2015)

\begin{tabular}{|c|c|c|c|c|c|c|c|c|c|}
\hline Num & Village & TPS Name & Cont. & $\begin{array}{l}\text { Volume/ } \\
\text { day }\left(\mathrm{m}^{3}\right)\end{array}$ & Num & Village & TPS Name & Cont. & $\begin{array}{l}\text { Volume/ } \\
\text { day }\left(\mathrm{m}^{3}\right)\end{array}$ \\
\hline 1 & Rowosari & - & 0 & \pm 1000 & 16 & \multirow[t]{10}{*}{ Sendangmulyo } & TPS Ketileng Atas & 1 & \multirow[t]{10}{*}{ \pm 5000} \\
\hline 2 & \multirow[t]{3}{*}{ Meteseh } & TPS Dinar Mas & 1 & \multirow[t]{3}{*}{ \pm 1500} & 17 & & TPS Ketileng Bawah & 1 & \\
\hline 3 & & TPS Bukit Kencana & 1 & & 18 & & TPS ASPOL Sd.Mulyo & 1 & \\
\hline 4 & & TPS Pasar Meteseh & 1 & & 19 & & TPS PSIS & 1 & \\
\hline 5 & Kramas & - & 0 & \pm 1000 & 20 & & TPS RSUD & 1 & \\
\hline 6 & \multirow[t]{3}{*}{ Tembalang } & TPS Politeknik & 1 & \multirow[t]{3}{*}{ \pm 4000} & 21 & & TPS Klipang & 1 & \\
\hline 7 & & TPS Tembalang & 4 & & 22 & & TPS Cempaka & 1 & \\
\hline 8 & & TPS Bukit Diponegoro & 1 & & 23 & & TPS Menur & 1 & \\
\hline 9 & Bulusan & - & & \pm 1000 & 24 & & TPS Tulus Harapan & 1 & \\
\hline 10 & \multirow[t]{2}{*}{ Mangunharjo } & TPS Jl. Elang Raya & 1 & \multirow[t]{2}{*}{ \pm 1000} & 25 & & TPS Keliling & 1 & \\
\hline 11 & & TPS Rumpun & 1 & & 26 & \multirow[t]{3}{*}{ Sambiroto } & TPS Salak Utama/Intan & 1 & \multirow[t]{3}{*}{ \pm 1500} \\
\hline 12 & \multirow[t]{2}{*}{ Tandang } & TPS Tandang & 1 & \multirow[t]{2}{*}{ \pm 1000} & 27 & & TPS Sambiroto RW VI \& VII & 1 & \\
\hline 13 & & TPS Rogojembangan & 1 & & 28 & & TPS Wana Mukti & 1 & \\
\hline 14 & Kedungmundu & TPS Kini Jaya & 1 & \pm 500 & 29 & Jangli & TPS TPS Jangli & 1 & \pm 500 \\
\hline 15 & Sendangguwo & TPS Sendangguwo & 1 & \pm 1000 & & & & & \\
\hline *Note & $\begin{array}{l}\text { TPS (Tempa } \\
\text { Cont. : Num }\end{array}$ & $\begin{array}{l}\text { embuangan Sampa } \\
\text { of Container }\end{array}$ & ne & ra) : Tem & orary & aste Disposal & & & \\
\hline
\end{tabular}




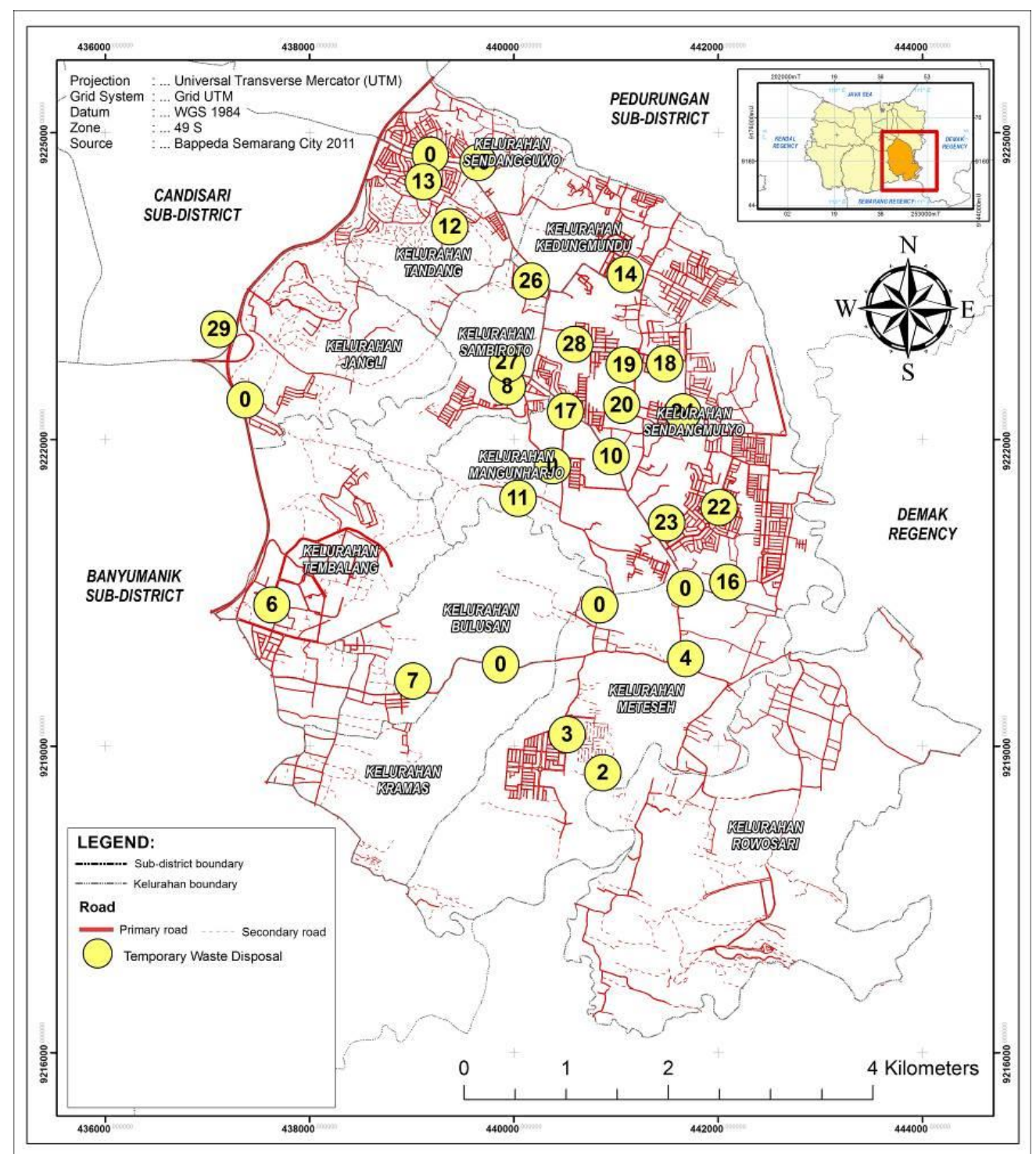

*Note: Number 0 indicates Open Dumping TPS

Figure 3. TPS Location Map (Observation, 2016)

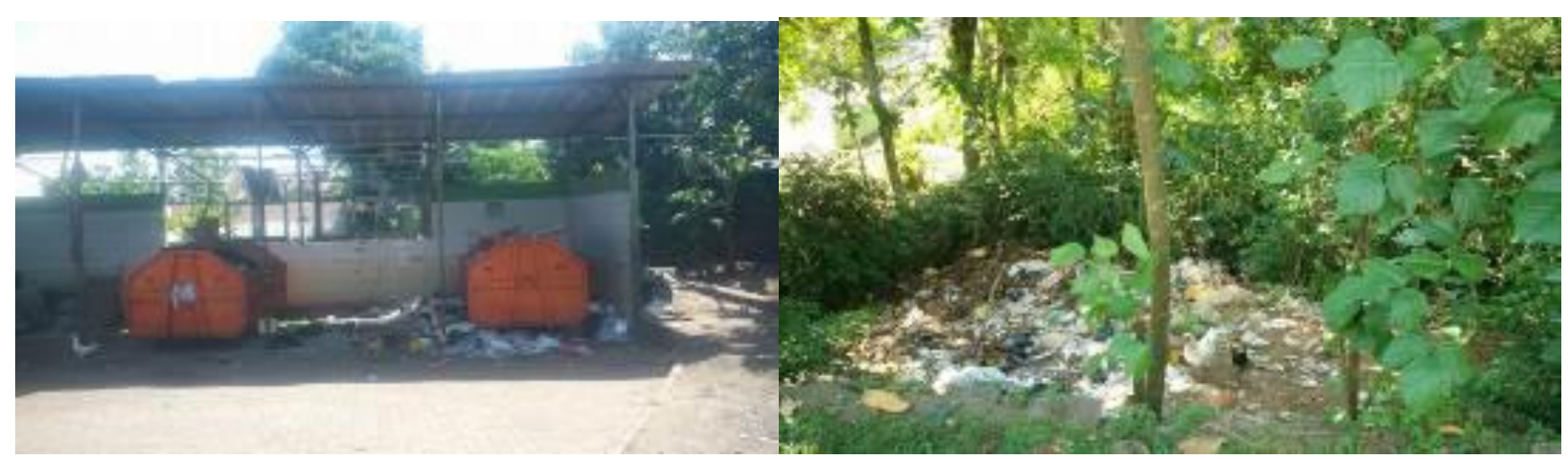

Figure 4. Temporary Waste Disposal Place \& Open Dumping Waste (Observation, 2016)

\subsubsection{Socio-economic data}

In this study, the data to be used as an independent variable influence on waste generation in Tembalang Sub-district are socio-economic variables (Table 2). Those variables consist of the total population, household size, and the number of trading activities. Here is the socio-economic data of Tembalang Sub-district in 2015. 
Table 2. Socio-economic data in Tembalang Sub-district (CBS, 2015)

\begin{tabular}{|c|c|c|c|c|c|c|}
\hline Num. & Village & Wide Area $\left(\mathrm{km}^{2}\right)$ & $\begin{array}{l}\text { Population } \\
\text { (person) }\end{array}$ & Household Size & Number of Trading Activities & $\begin{array}{c}\text { Density } \\
\left(\text { people } / \mathrm{km}^{2}\right)\end{array}$ \\
\hline 1 & Rowosari & 8.7 & 11019 & 3214 & 84 & 1316 \\
\hline 2 & Meteseh & 4.99 & 15621 & 4888 & 383 & 2669 \\
\hline 3 & Kramas & 0.93 & 3384 & 1024 & 15 & 1311 \\
\hline 4 & Tembalang & 2.68 & 5519 & 1294 & 75 & 1480 \\
\hline 5 & Bulusan & 3.04 & 5125 & 1588 & 147 & 1772 \\
\hline 6 & Mangunharjo & 3.03 & 8468 & 2532 & 68 & 3552 \\
\hline 7 & Sendangmulyo & 4.61 & 33697 & 10440 & 622 & 5855 \\
\hline 8 & Sambiroto & 3.18 & 12357 & 3584 & 84 & 6548 \\
\hline 9 & Jangli & 2.07 & 6402 & 1676 & 13 & 2208 \\
\hline 10 & Tandang & 3.75 & 20382 & 6115 & 104 & 10744 \\
\hline 11 & Kedungmundu & 1.49 & 11127 & 2883 & 156 & 5680 \\
\hline \multirow[t]{2}{*}{12} & Sendangguwo & 3.27 & 21596 & 5997 & 87 & 17396 \\
\hline & TOTAL & 41.74 & 154697 & 45235 & 1838 & \\
\hline
\end{tabular}

\subsection{Analytical Procedure}

The research sample location is the whole Temporary Waste Disposal (TPS) in each village which then the results of observations and obtained data are to be used as input for the analysis of total community waste production. From the distribution of point locations in the study area, model in the term of spatial aspect spreading can be observed. The author also finds the relationship between the community waste generation by factors that affect the amount of waste. In this case, the author only uses socio-economic variables as independent variable. The relationship is modeled into an equation by using Ordinary Least Square (OLS). The software used for Ordinary Least Square Analysis is ArcMap 10.1.

\subsection{Spatial Statistics using GIS for mapping}

Spatial Statistics is a tool of analysis in a Geographic Information System that serves to analyze the spatial distribution, spatial patterns, processes, and spatial relationships. While there may be similarities between the spatial and non-spatial (traditional) statistics in terms of concepts and objectives, spatial statistical uniquely developed specifically used for data concerning spatial geographic. Spatial Statistics combines the space of distance, area, connectivity and spatial relationships directly by using math. Statistical analysis is also used to identify and confirm the form of spatial patterns, such as the centralization of the group, finding out the trend direction, or whether to form a cluster. Statistical functions analyze the underlying data and provide some measures that can be used to determine the existence and strength of the pattern. Spatial statistics contains cluster analysis which takes formed cluster pattern into account.

\subsubsection{Average Nearest Neighbor \& Hot-Spot Analysis}

Average Nearest Neighbor is one of analysis used to explain the distribution pattern of location points by using a calculation that considers distance, the number of location points, and total area. This analysis requires data regarding the distance between the settlements with the closest settlement which is settlement nearest neighbor. Average Neighbor Analysis calculates the distance between each feature and the nearest neighbor, then computes the data for the entire distance of the nearby neighborhood. The output of the Average Nearest Neighbor analysis is in a form of a Z-Score and P-value index that indicate whether the case is clustered, random or dispersed. Before analyzing, the requirement to obtain a Z-Score is to know the extent of the territory within the limits of the study, in this case is Tembalang Sub-district. Based on calculations by using Arc Map application, the total area of Tembalang Sub-district is 41,452,310 
$\mathrm{m}^{2}$. The input data to be processed is the data of point results of waste disposal sites scattered around Tembalang Sub-district.

Nearest Neighbor Index describes the ratio of the observed distance median value to the expected distance median value. The expected distance is the mean distance between neighbors in random distribution hypothesis. If the index is less than 1, the pattern shows a grouping (Cluster); if the index is greater than 1, the trend is spreading. In Average Nearest Neighbor analysis, there is also significance level ( $p$-value) and the critical value (z-score). Both these values are worth $0.01 \rightarrow 2.58$. P-value and Z-score indicate whether $\mathrm{HO}$ is rejected or not. In Average Nearest Neighbor, HO indicates that features are randomly distributed. If the Z-score has a value $<-1.65$, then the cluster will more likely to shape. Whereas if it is $>1.65$, the pattern will be more random.

Hot Spot is the concentration of the incident with the geographic area boundaries that appear from time to time. Hot Spot can also be used to assess concentrations of specific land use, or between activity and land use (Block \& Block, 1995). Hot Spot may not exist in real life, but it represents where there is a concentration of activities or specific cases so that the area can be labeled as areas of high concentration. There are dozens of statistical analysis techniques to identify the Hot Spot (Everiit, 1974). Most of the statistical analysis technique used is commonly called cluster analysis. This is a technique of grouping together cases in a relatively coherent group. Because the Hot Spot is a perception construction, the techniques must use an approach on how one understands the study area. Here are a few types of methods Hot Spot / Cluster analysis (Everiit \& Megbolugbe, 1996) :

1. Point Location

2. Hierarchical Techniques

3. Partitioning Techniques

4. Density Techniques

5. Clumping Techniques

6. Risk-based Techniques

7. Miscellaneous Techniques

\subsubsection{Spatial Pattern}

According to Tobler in his book "The First Law of Geography", he revealed that all things are always related to everything else, but something closer is to have more influence than something far (Tobler, 1970) a spatial autocorrelation. Spatial cluster is a positive spatial autocorrelation when there are similar values forming cluster, while the opposite is if there are separate values called as negative spatial autocorrelation (Boots \& Getis, 1988). The spatial clusters can help the understanding of geographic processes underlying the relationship with the phenomenon under study. Based on existing spatial clusters, there will be formed different spatial patterns. Spatial Pattern is something that shows the placement or arrangement of objects on the Earth's surface (Lee \& Wong, 2001). The spatial pattern will explain how geographic phenomena is distributed and how it compares with other phenomena. The spatial pattern can be either a point or area (Polygon), and they can form a pattern of clustered, dispersed, and random.

\subsubsection{Modeling using Ordinary Least Square Regression}

As with the simple linear equation regression analysis, the basic idea behind OLS is to explore the relationship between a dependent variable $(\mathrm{Y})$ and one or more independent variables (the $\left.\mathrm{X}^{\prime} \mathrm{s}\right)$. The simple model of OLS equation can be expressed as (Ryan, 1996), which is defined as follows:

where

$$
y_{i}=\beta_{0}+\sum_{k} \beta_{k} x_{i k}+\varepsilon_{i}
$$

- $\left\{x_{i k}\right\}$ are observations for $\mathrm{i}=1, . ., \mathrm{n}$ cases and $\mathrm{k}=1, . ., \mathrm{m}$ explanatory variables,

- $\left\{y_{i}\right\}$ are the dependent variables,

- $\quad \beta$ 's are the estimates of the coefficients,

- and $E$ 's are normally distributed error terms. 


\section{RESULTS AND DISCUSSION}

\subsection{Average Nearest Neighbor \& Hot Spot of Waste Generation}

Under the table shows that the expected mean distance between one point to another point is 578 meters, however, the real condition is that the observed mean distance between one point to another point is 560 meters (Table 3 ). The value of $z$-score value is -0.326302 because the value is $>-1.65$, so the case of observation points forms a random pattern. More details are shown in the following figure.

Table 3. Calculation Results of Average Nearest Neighbor Analysis (Analysis, 2016)

\begin{tabular}{ccc}
\hline Explanation & Result \\
Observed Mean Distance & 560.468465 Meters \\
\hline Expected Mean Distance & 578.180614 Meters \\
\hline Nearest Neighbor Ratio & 0.969366 \\
\hline z-score & -0.326302 \\
\hline p-value & 0.744196
\end{tabular}

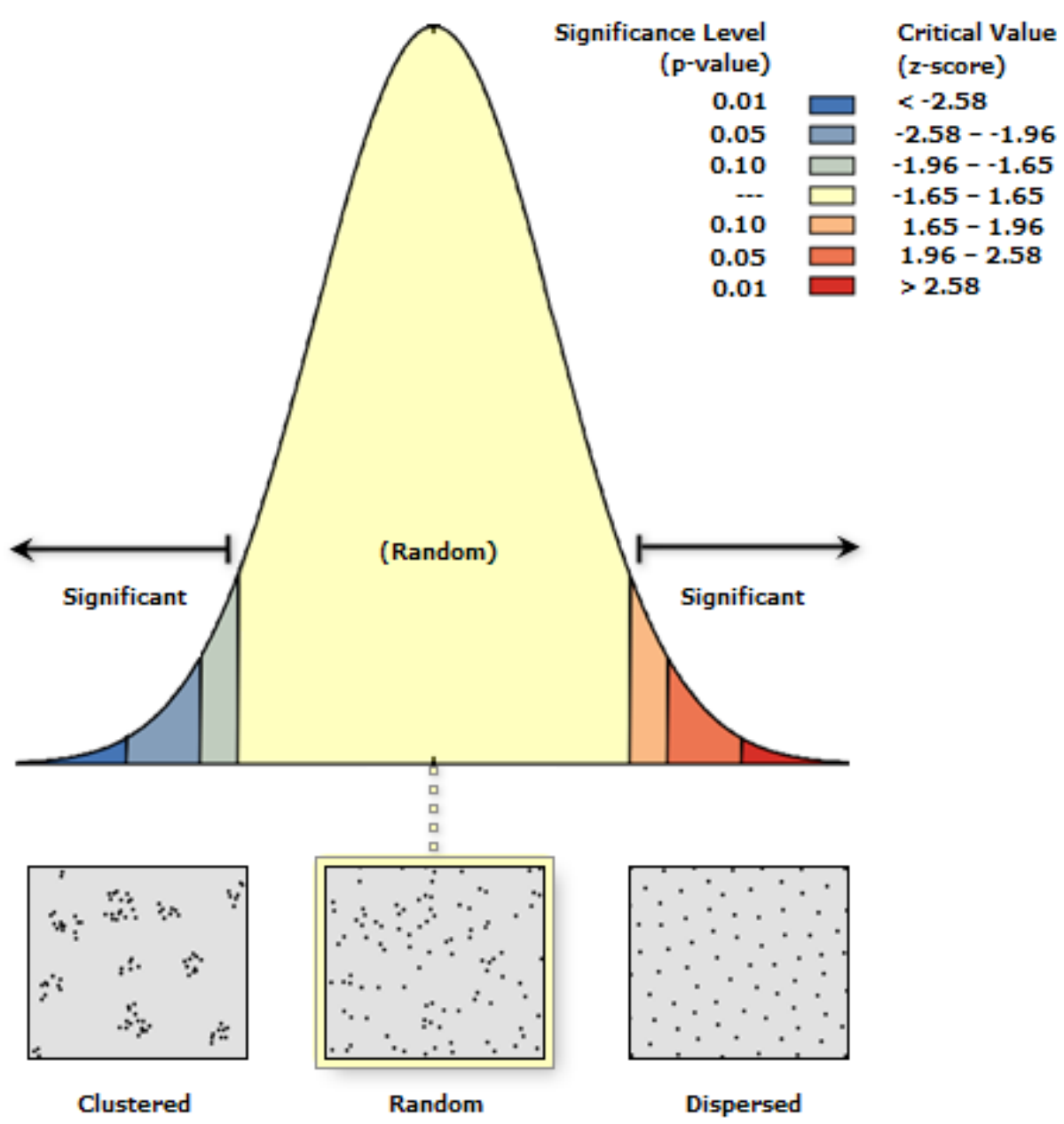

Figure 5. Result Diagram of Average Nearest Neighbor Analysis (Analysis, 2016)

Hot Spot Analysis on waste generation uses attributes of the average amount of waste disposal per capita / day. Hot Spot Analysis is performed by using analysis tools in Arc Map named "Hot Spot Analysis (Getis-Ord-Gi')" (Figure 5). In addition to the above attributes, the maximum distance of each household in one sub-district is required based on the previous analysis result. So, the author uses observed mean 
distance as a threshold which is 560 meters. Based on the input data in the Arc Map application, the Hot Spot result is obtained as follows.

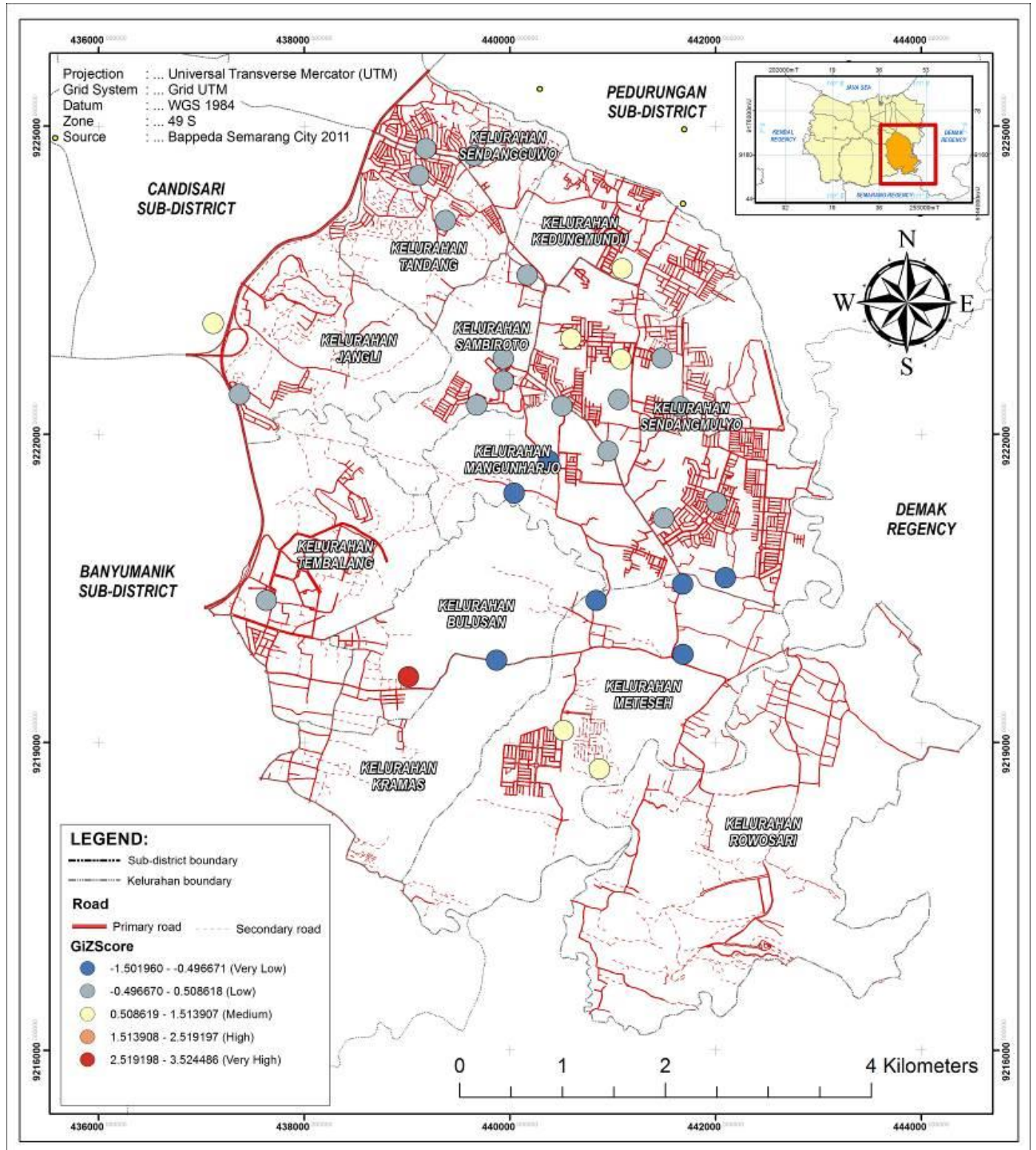

Figure 6. Result Map of Hot Spot Analysis (Analysis, 2016)

Based on the picture (Figure 6), the hotspots show the occurring concentration of solid waste generation. There are two main colors namely red and blue. The red color indicates the higher concentration of waste generation while blue color conversely indicates the lower concentration. The yellow color indicates the medium concentration. TPS Tembalang has the hot spot, so it means in this place amount of solid waste generation agglomerated here.

\subsection{Spatial Pattern of Solid Waste Generation}

Spatial Pattern Analysis of Solid Waste Generation is carried out by using the input feature from the Hot Spot result of waste generation. Hot-Spot points are interpolated according to the attributes similarity so it will make up the classification class to be determined. Here is a picture interpolated hot spot. 


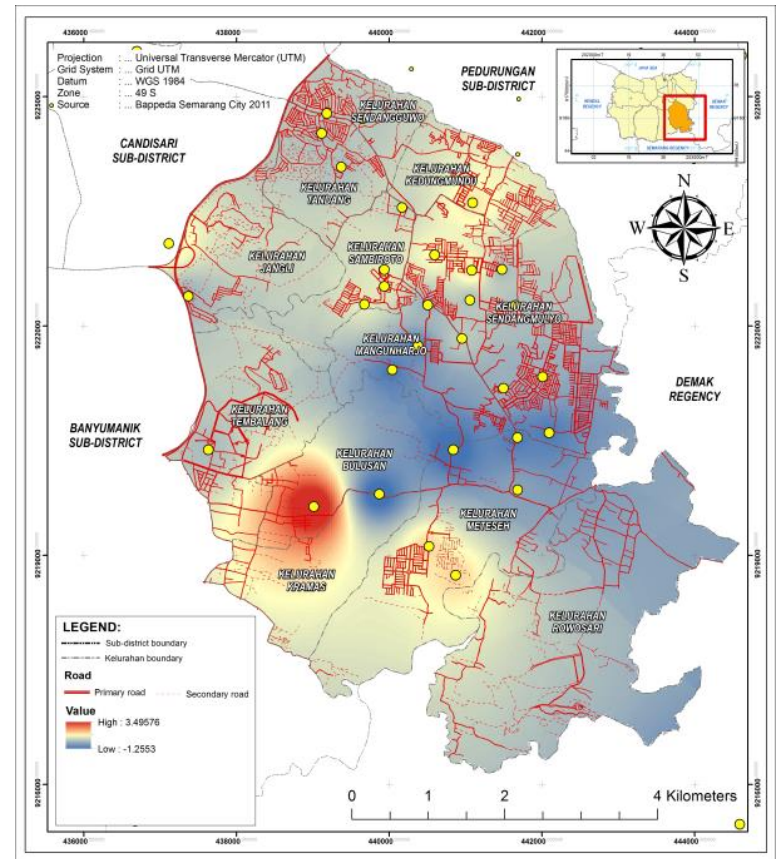

Figure 7. Spatial Patterns Map of Interpolation (Analysis, 2016)

Based on the following image (Figure 7), the color gradation of blue-yellow-red indicates the concentration of waste in landfills. The bluer the color indicates the less and more insufficient amount of waste generation. While the redder the color indicates that the amount of waste has exceeded its capacity. From the map, it appears that a pretty solid waste generation are around the area of Sendangmulyo and Meteseh. While the area that has a solid waste, generation is around the area of Tembalang Village.

\subsection{Modelling Solid Waste Generation}

In making the equation model of waste generation in Tembalang Sub-district, OLS analysis is used as supporting equipment. The dependent variable in the model is the data of waste generation, while the independent variable is a variable of socio-economic characteristics including the number of populations, number of households, population density, and the amount of trading activity. Here are the results of the processed data by using Spatial Statistics analysis in ArcMap 10.1:

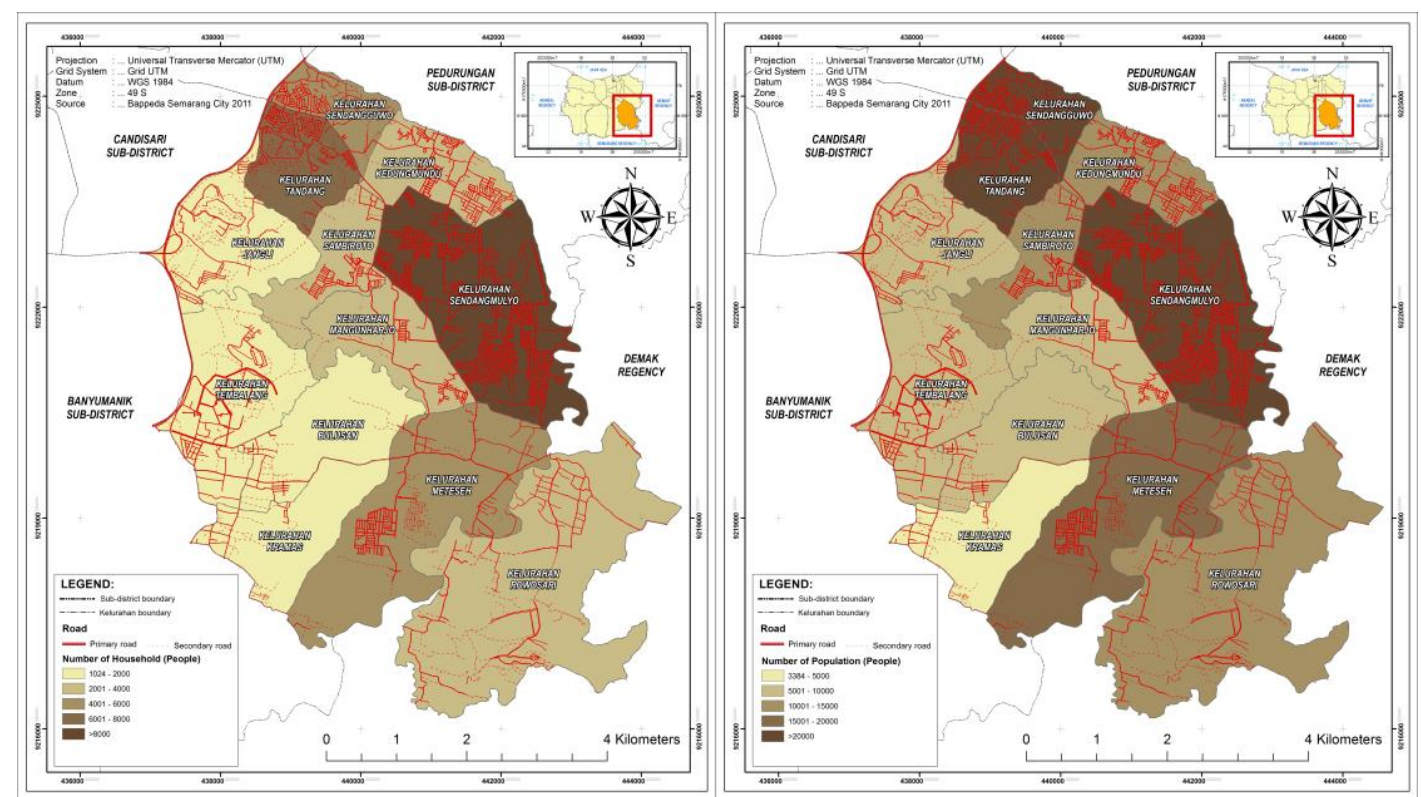

Figure 8. Number of Household \& Number of Population Map (Bappeda ${ }^{1}$, 2011)

${ }^{1}$ Bappeda (Badan Perencanaan Pembangunan Daerah): Regional Development Planning Agency 


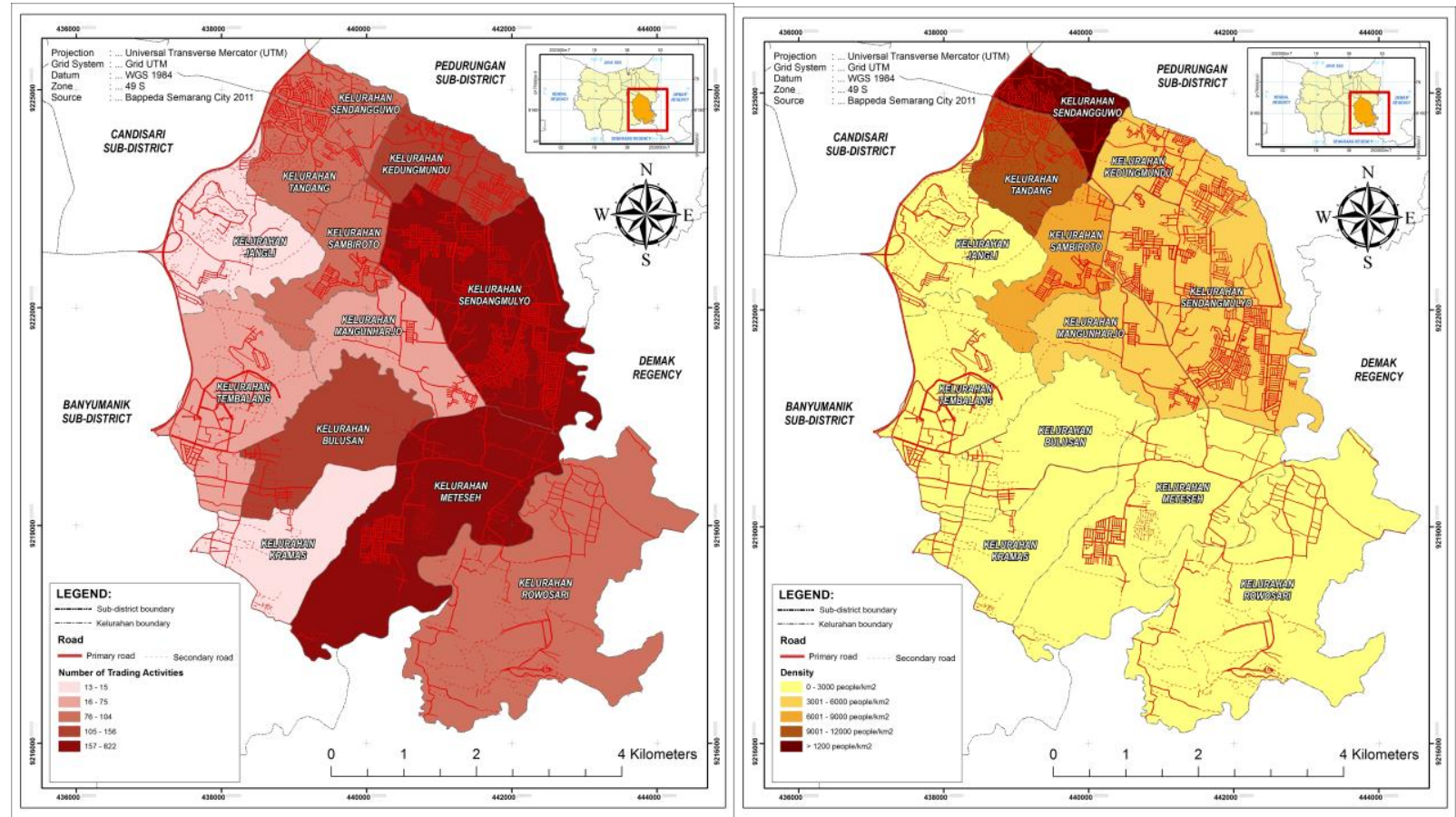

Figure 9. Total Number of Trading Activities \& Number of Density Map (Bappeda, 2011)

$$
Y=398.776650+0.720890 X_{1}-1.972677 X_{2}+2.317599 X_{3}-0.203706 X_{4}
$$

Where:

$\begin{array}{llll}Y & \text { : Solid Waste Generation } & X_{3} & : \text { Number of Trading Activities } \\ X_{1} & \text { : Number of Population } & X_{4} & : \text { Number of Density } \\ X_{2} & : \text { Number of Household } & & \end{array}$

The results of Adjusted R-Squared $\left(R^{2}\right)$ analysis indicates the value of 0.253366 . This shows that the percentage of independent variable influence contribution towards the dependent variable is $25 \%$. This means that there are other variables that affect the amount of society waste generation. Based on the above linear equation, the coefficients which have positive value towards waste generation are population and trading activities, while the coefficients which have negative value are the number of household and density. This equation explains that the increase of population and trading activities will intensify the production of waste generation. While the number of household and density don't necessarily affect the amount of waste generation in Tembalang Sub-district.

\subsection{Discussion}

According to the spatial pattern map identified by the amount of solid waste generation, it can be seen that the dominant red color is in TPS Tembalang (TPS number 7). This is because TPS Tembalang accommodates waste from three villages namely Rowosari, Kramas, and Bulusan. Although TPS Tembalang has a considerable number of containers, but it is still not able to accommodate all waste from those three villages. Another factor that led to the amount of waste in TPS Tembalang is due to the presence of Diponegoro University. The existence of Diponegoro University causes the growth of residential areas, trading activities, and the increasing number of students who live in the area around Tembalang. The second largest waste generation is in TPS Sendangmulyo mainly caused by the fact that Sendangmulyo has the largest population in Tembalang Sub-district. The presence of market and trading activities also cause this sub-district is very noteworthy. This is in line with Yousif \& Scott (2007) argument on how the amount of waste's growth in cities is driven by rapid population increase and economic expansion. Recommendations that can be applied in the Tembalang Sub-district is the need to create new TPS in the Kramas and Rowosari. Ideally, every village must have at least one TPS. Because the socio-economic 
variable that contains the model of waste generation models influence only $25 \%$, this means that there are other variables that affect the increase in the amount of waste generation (Lee et al,. 2015). Therefore, the author recommends further research to add variables such as culture (lifestyle), the income of people (more detailed), and land use (spatial aspects) to be able to make a more complete model.

\section{CONCLUSION}

Based on the performed OLS result in the study area of Tembalang Sub-district, socio-economic variables that influence waste generation are variables of population and the number of trading activities. The growing number of residents and trading activities will affect the amount of waste generation. The results of the relationship model between the dependent variable (waste generation) with independent variables (population, the number of households, trading activities, and density) have an effect of $25 \%$. It means there needs to be a search for other variables that can affect the amount of waste generation in Tembalang Sub-district. Spatial patterns identified from the waste generation in Tembalang Sub-district shows that TPS Tembalang in Bulusan Village is red. It indicates the need for special handling in that location. TPS Tembalang accommodates garbage from three villages namely Rowosari, Bulusan, and Kramas. However, the number of containers to accommodate the amount of community waste is still lacking. Therefore, it is necessary to establish new TPS in the Village of Rowosari, Kramas, and Bulusan. By using spatial statistics, we can map, search for relationships between variables and model a case around us. Observing previous studies of a case in terms of the spatial view would make it more easily understood and solved. Spatial Statistics by using GIS is not only to be used for waste disposal or waste generation but can also be used in the case of health, crime, transport, etc. The author also suggests forming models using other variables related to waste piles such as economic, demographic, physical and other factors.

\section{ACKNOWLEDGMENTS}

The author would like to give an appreciation to the anonymous reviewer who has provided a lot of input during the writing of this paper. This study is supported by Indonesia Endowment Fund for Education (LPDP) Ministry of Economic in Indonesia. The author thanks the lecturers in Master Program of Urban and Regional Planning Development for providing supports to this research.

\section{REFERENCES}

Bappeda. (2011). Spatial Planning Development Document. Semarang.

Block, R. L., \& Block, C. R. (1995). Space, place and crime: Hot spot areas and hot places of liquor-related crime. Crime and Place, 4(2), 145-184.

Boots, B. N., \& Getis, A. (1988). Point pattern analysis (Vol. 8). SAGE Publications, Incorporated.

CBS. (2015). Tembalang Sub-district in Figures. Semarang: Central Bureau of Statistics.

Damanhuri, E., Wahyu, I. M., \& Padmi, T. (2010). Evaluation of waste recycling potential in Bandung Municipal Solid Waste. World Review of Science, Technology and Sustainable Development, 7(3), 282. [Crossref]

DKP. (2015). Number of Waste Generation in Tembalang Sub-district. Semarang.

Everiit, B. (1974). Cluster Analysis, London: Heinemann Education Books.

Everiit, B., \& Megbolugbe, I. (1996). The Geography of Underserved Mortgage Markets. American Real Estate and Urban Economics Association Meeting.

JICA. (2005). Supporting Capacity Development in Solid Waste Management in Developing Countries; Towards Improving Solid Waste Management Capacity of Entire Society. Tokyo.

Lee, D., Kung, K., \& Ratti, C. (2015). Mapping the Waste Handling Dynamics in Mombasa Using Mobile Phone GPS. In Proceedings of The 14th International Conference on Computers in Urban Planning and Urban Management.

Lee, J., \& Wong, D. W. . (2001). Statistical Analysis with ArcView GIS. New York: John Wiley \& Sons Inc. 
Moersid, M. M. (2004). Konsep National Action Plan Pengelolaan Sampah dalam Rangka Millenium Development Goals. Semarang: Dalam acara Kajian Pengelolaan Sampah Secara Terintegrasi.

Olukanni, D., and Oladipupo Akinyinka, Ede, A., Akinwumi, I., Ajanaku, K., \& and. (2014). Appraisal of Municipal Solid Waste Management, Its Effect and Resource Potential in a Semi-Urban City: a Case Study. Journal of South African Business Research, 1-13. [Crossref]

Ryan, T. P. (1996). Modern Regression Methods. Chichester: John Wiley and Sons.

Tobler, W. R. (1970). A Computer Movie Simulating Urban Growth in the Detroit Region. Economic Geography, 46, 234. [Crossref]

Yousif, D. F., \& Scott, S. (2007). Governing solid waste management in Mazatenango, Guatemala: Problems and prospects. International Development Planning Review, 29(4), 433-450 [Crossref] 